\title{
Focus on blood pressure targets and vasopressors in critically ill patients
}

\author{
Anders Perner ${ }^{1 *}$ (D) Peter B. Hjortrup ${ }^{2}$ and Yaseen Arabi ${ }^{3}$ (D)
}

(c) 2019 Springer-Verlag GmbH Germany, part of Springer Nature

For patients in shock, decisions on blood pressure targets are an ongoing task for the clinicians at the bedside in critical care settings. In general, there are only limited amount of data from studies with lower risk of bias to support the clinicians in these decisions. However, in recent years, large cohort studies and randomised clinical trials (RCTs) have given us somewhat better data to support better care.

What blood pressure target is chosen will likely have important clinical implications, not only because different blood pressure targets may affect organ perfusion differently, but also because they require different dosing and choices of vasopressor agents. A delicate balance likely exists between the consequences of hypotension-induced hypoperfusion, on one side, and on the other side, the consequences of the interventions given, mainly vasopressors and their dosages and the duration of administration.

In a large registry study from 110 ICUs in the US, hypotension-as time-weighted averages-in patients with sepsis was associated with increased risk of myocardial injury, acute kidney injury and death [1]. For the two latter outcomes, the odds for worse outcome increased with decreasing mean arterial pressures (MAP) from $85 \mathrm{mmHg}$. This does not mean that we should apply $85 \mathrm{mmHg}$ as the target for vasopressor therapy, because observational data cannot prove causality and any timedependent interactions with interventions and any other physiological markers are very difficult to control for in such analyses [2-4]. In addition, registry data often contain few or no data on important clinical markers, in this

*Correspondence: anders.perner@regionh.dk

${ }^{1}$ Department of Intensive Care, Rigshospitalet, University of Copenhagen, Copenhagen, Denmark

Full author information is available at the end of the article case the simple markers of peripheral perfusion, which likely interacts with any effects of hypotension on mortality [5, 6]. Importantly, a recent individual patient data meta-analysis (IPDMA) of two RCTs [7, 8] of lower vs. higher blood pressure targets in ICU patients with shock suggested that no sub-groups were harmed from lower MAP targets [9]. If anything, two sub-groups of patients were harmed from a higher MAP target being patients with more than $6 \mathrm{~h}$ of vasopressor exposure before randomization and those aged 65 years or above. Taken together, clinical equipoise exists [10], and more RCTs on blood pressure targets in shock patients are underway, including the large 65-trial on permissive hypotension in patients aged above 65-year who have shock (ISRCTN10580502). The results of the 65-trial should be presented soon as enrolment has ended. Uncertainty may remain regarding the need to individualize blood pressure targets based on habitual blood pressure levels or the trajectory of critical illness, e.g., the phases of resuscitation, stabilization and recovery.

The choice of vasopressor to obtain the blood pressure target is also likely to matter. A recent multicenter, blinded RCT of the longer-acting vasopressin-analogue terlipressin, which has higher affinity for the $\mathrm{V}_{1 \mathrm{a}}$ receptor, showed no effect on the primary outcome 28-day mortality as compared with noradrenalin in patients with septic shock (Table 1) [11]. More serious adverse events were observed with terlipressin; more specifically, there were more patients with digital ischemia in the vasopressinanalogue group [11]. The accompanying editorial comment warned that care should be taken if this vasopressor is used [12]. In addition, these results may further support that noradrenalin should be the first line vasopressor in patients with shock [13].

The use of noradrenalin as compared to vasopressin (the endogenous hormone arginine-vasopressin, which is shorter acting than terlipressin) will likely result in 
Table 1 Larger randomized trials of vasopressin or its analogues vs. noradrenalin in critically ill patients

\begin{tabular}{|c|c|c|c|c|c|}
\hline Trial & Registration & PICO & Sample size & Primary result & Serious adverse events \\
\hline VASST & ISRCTN 94845869 & $\begin{array}{l}\text { P: septic shock } \\
\text { I: vasopressin infusion } \\
\text { C: noradrenalin infusion } \\
\text { O: 28-day mortality }\end{array}$ & $\begin{array}{l}\text { Planned 776, enrolled } \\
778\end{array}$ & $\begin{array}{l}\text { 28-day mortality 35\% } \\
\text { vs. } 39 \%\end{array}$ & $10 \%$ vs. $11 \%$ \\
\hline VANISH $H^{a}$ & ISRCTN 20769191 & $\begin{array}{l}\text { P: septic shock } \\
\text { I: vasopressin infusion } \\
\text { C: noradrenalin infusion } \\
\text { O: kidney failure free } \\
\text { days at day } 28\end{array}$ & $\begin{array}{l}\text { Planned 412, enrolled } \\
421\end{array}$ & $\begin{array}{l}\text { Kidney failure free } \\
\text { days at day } 28,9 \text { vs. } \\
13 \text { days }^{b}\end{array}$ & $11 \%$ vs. $8 \%$ \\
\hline $\begin{array}{l}\text { Multicenter, prospec- } \\
\text { tive, randomized, } \\
\text { controlled, double- } \\
\text { blind study in China to } \\
\text { evaluate the effect of } \\
\text { terlipressin in patients } \\
\text { with septic shock }\end{array}$ & NCT 01697410 & $\begin{array}{l}\text { P: septic shock } \\
\text { I: terlipressin infusion } \\
\text { C: noradrenalin infusion } \\
\text { O: } 28 \text {-day mortality }\end{array}$ & $\begin{array}{l}\text { Planned 1000, enrolled } \\
617\end{array}$ & $\begin{array}{l}\text { 28-day mortality } 40 \% \\
\quad \text { vs. } 38 \%\end{array}$ & $30 \%$ vs. $12 \%$ \\
\hline SEPSIS-ACT & NCT 02508649 & $\begin{array}{l}\text { P: septic shock } \\
\text { I: selepressin infusion } \\
\text { C: noradrenalin infusion } \\
\text { O: vasopressor- and } \\
\text { mechanical ventilator- } \\
\text { free days at day } 30\end{array}$ & $\begin{array}{l}\text { Planned } 1800^{\circ} \text {, enrolled } \\
868\end{array}$ & Pending & Pending \\
\hline \multicolumn{6}{|c|}{ PICO patients, intervention, comparator, outcome } \\
\hline \multicolumn{6}{|c|}{ a Bifactorial design with co-allocation to hydrocortisone vs. placebo } \\
\hline \multicolumn{6}{|c|}{ b Survivors who never developed kidney failure: vasopressin 57\% and noradrenalin 59\% } \\
\hline & & & & & \\
\hline
\end{tabular}

more episodes of atrial fibrillation as observed in a recent IPDMA [14]. Also, in this analysis, more episodes of digital ischemia were observed with vasopressin as compared to noradrenalin. While we await the publication of the largest RCT on vasopressin-analogues in septic shock, the SEPSIS-ACT trial on the short-acting $\mathrm{V}_{1 \mathrm{a}}$-specific analogue selepressin [15] (Table 1), the cumulative evidence on the effects of vasopressin and its analogues vs. noradrenalin in patients with septic shock appears to be that the choice does not affect mortality (Table 1), the vasopressin and its analogues cause higher incidences of digital ischemia and noradrenalin causes higher incidences of atrial fibrillation. The choice between vasopressin and its analogues vs. noradrenalin may therefore rely on the risk for the specific patient for these adverse events, the costs of the agents and the knowledge of the staff who are to infuse and monitor the patient. However, simplification of care has rational in general and adding vasopressin as a second vasopressor in patients with shock adds additional complexity to the care of these patients.

A third vasopressor, angiotensin II, was recently tested as an add on to other vasopressors, mainly being combined noradrenalin and vasopressin, in 344 ICU patients with vasodilatory shock in the placebo-controlled ATHOS-3 trial [16]. Angiotensin II clearly increased blood pressure (the primary outcome) and decreased the administration of other vasopressors as compared with placebo. While no apparent differences in adverse effects were observed in the ATHOS-3 trial, angiotensin-II cannot be recommended in patients with shock given the limited safety data and the cost of this vasopressor.

An additional issue is the critically ill patients who have continued vasoplegia for a prolonged time-period. In these there may be a role for oral vasopressor treatment, e.g., midodrine, to promote liberation from central lines, mobilization, de-escalation of the monitoring level and ICU discharge [17, 18].

Finally, the results of the above studies do little in answering the more controversial question, should we target blood pressure at all? If our aim is to improve outcome through improved mitochondrial, cellular and/ or tissue function, blood pressure may be a very distant marker to target? In any case, assessing different aspects of current clinical practice will improve the care of our patients while we await the results of the difficult clinical studies that may enlighten us about the better targets.

\footnotetext{
Author details

${ }^{1}$ Department of Intensive Care, Rigshospitalet, University of Copenhagen, Copenhagen, Denmark. ${ }^{2}$ Department of Anaesthesia and Intensive Care, Zealand University Hospital, Køge, Denmark. ${ }^{3}$ College of Medicine, King Abdullah International Medical Research Center and Intensive Care Department, King Abdulaziz Medical City, King Saud Bin Abdulaziz University for Health Sciences, Riyadh, Kingdom of Saudi Arabia.
} 


\section{Compliance with ethical standards}

\section{Conflicts of interest}

The Department of Intensive Care, Rigshospitalet receives support for research from Ferring Pharmaceuticals and the Novo Nordisk Foundation.

\section{Publisher's Note}

Springer Nature remains neutral with regard to jurisdictional claims in published maps and institutional affiliations.

Received: 11 June 2019 Accepted: 27 July 2019

Published online: 5 August 2019

\section{References}

1. Maheshwari K, Nathanson BH, Munson SH, Khangulov V, Stevens M, Badani H, Khanna AK, Sessler DI (2018) The relationship between ICU hypotension and in-hospital mortality and morbidity in septic patients. Intensive Care Med 44:857-867

2. Sessler DI, Khanna AK (2018) Perioperative myocardial injury and the contribution of hypotension. Intensive Care Med 44:811-822

3. Asfar P, Radermacher P, Ostermann M (2018) MAP of 65: target of the past? Intensive Care Med 44:1551-1552

4. Perner A, Bellomo R, Moller MH (2019) Is research from databases reliable? No. Intensive Care Med 45:115-117

5. Lavillegrand JR, Dumas G, Bige N, Zafimahazo D, Guidet B, Maury E, Ait-Oufella H (2018) Should we treat mild hypotension in septic patients in the absence of peripheral tissue hypoperfusion? Intensive Care Med 44:1593-1594

6. Hernandez G, Ospina-Tascon GA, Damiani LP, Estenssoro E, Dubin A, Hurtado J, Friedman G, Castro R, Alegria L, Teboul JL, Cecconi M, Ferri G, Jibaja M, Pairumani R, Fernandez P, Barahona D, Granda-Luna V, Cavalcanti AB, Bakker $J$, The ASI, the Latin America Intensive Care N, Hernandez G, Ospina-Tascon G, Petri Damiani L, Estenssoro E, Dubin A, Hurtado J, Friedman G, Castro R, Alegria L, Teboul JL, Cecconi M, Cecconi M, Ferri G, Jibaja M, Pairumani R, Fernandez P, Barahona D, Cavalcanti AB, Bakker J, Hernandez G, Alegria L, Ferri G, Rodriguez N, Holger P, Soto N, Pozo M, Bakker J, Cook D, Vincent JL, Rhodes A, Kavanagh BP, Dellinger P, Rietdijk W, Carpio D, Pavez N, Henriquez E, Bravo S, Valenzuela ED, Vera M, Dreyse J, Oviedo V, Cid MA, Larroulet M, Petruska E, Sarabia C, Gallardo D, Sanchez JE, Gonzalez H, Arancibia JM, Munoz A, Ramirez G, Aravena F, Aquevedo A, Zambrano F, Bozinovic M, Valle F, Ramirez M, Rossel V, Munoz P, Ceballos C, Esveile C, Carmona C, Candia E, Mendoza D, Sanchez A, Ponce D, Ponce D, Lastra J, Nahuelpan B, Fasce F, Luengo C, Medel N, Cortes C, Campassi L, Rubatto P. Horna N, Furche M, Pendino JC, Bettini L, Lovesio C, Gonzalez MC, Rodruguez J, Canales H, Caminos F, Galletti C, Minoldo E, Aramburu MJ, Olmos D, Nin N, Tenzi J, Quiroga C, Lacuesta P, Gaudin A, Pais R, Silvestre A, Olivera G, Rieppi G, Berrutti D, Ochoa M, Cobos P, Vintimilla F, Ramirez V, Tobar M, Garcia F, Picoita F, Remache N, Granda V, Paredes F, Barzallo E, Garces P, Guerrero F, Salazar S, Torres G, Tana C, Calahorrano J, Solis F, Torres P, Herrera L, Ornes A, Perez V, Delgado G, Lopez A, Espinosa E, Moreira J, Salcedo B, Villacres I, Suing J, Lopez M, Gomez L, Toctaquiza G, Cadena Zapata M, Orazabal MA, Pardo Espejo R, Jimenez J, Calderon A, Paredes G, Barberan JL, Moya T, Atehortua H, Sabogal R, Ortiz G, Lara A, Sanchez F, Hernan Portilla A, Davila H, Mora JA, Calderon LE, Alvarez I, Escobar E, Bejarano A, Bustamante LA, Aldana JL (2019) Effect of a resuscitation strategy targeting peripheral perfusion status vs serum lactate levels on 28-day mortality among patients with septic shock: the ANDROMEDASHOCK randomized clinical trial. JAMA 321:654-664

7. Asfar P, Meziani F, Hamel JF, Grelon F, Megarbane B, Anguel N, Mira JP, Dequin PF, Gergaud S, Weiss N, Legay F, Le TY, Conrad M, Robert R, Gonzalez F, Guitton C, Tamion F, Tonnelier JM, Guezennec P, Van Der Linden T, VieillardBaron A, Mariotte E, Pradel G, Lesieur O, Ricard JD, Herve F, Du CD, Guerin C, Mercat A, Teboul JL, Radermacher P (2014) High versus low blood-pressure target in patients with septic shock. N Engl J Med 370:1583-1593

8. Lamontagne F, Meade MO, Hebert PC, Asfar P, Lauzier F, Seely AJE, Day AG, Mehta S, Muscedere J, Bagshaw SM, Ferguson ND, Cook DJ, Kanji S, Turgeon AF, Herridge MS, Subramanian S, Lacroix J, Adhikari NKJ, Scales DC, Fox-Robichaud A, SkrobikY, Whitlock RP, Green RS, Koo KKY, Tanguay T, Magder S, Heyland DK (2016) Higher versus lower blood pressure targets for vasopressor therapy in shock: a multicentre pilot randomized controlled trial. Intensive Care Med 42:542-550

9. Lamontagne F, Day AG, Meade MO, Cook DJ, Guyatt GH, Hylands M, Radermacher P, Chretien JM, Beaudoin N, Hebert P, D'Aragon F, Meziani F, Asfar P (2018) Pooled analysis of higher versus lower blood pressure targets for vasopressor therapy septic and vasodilatory shock. Intensive Care Med 44:12-21

10. Lamontagne F, Marshall JC, Adhikari NKJ (2018) Permissive hypotension during shock resuscitation: equipoise in all patients? Intensive Care Med 44:87-90

11. Liu ZM, Chen J, Kou Q, Lin Q, Huang X, Tang Z, Kang Y, Li K, Zhou L, Song Q Sun T, Zhao L, Wang X, He X, Wang C, Wu B, Lin J, Yuan S, Gu Q, Qian K, Shi X, Feng Y, Lin A, He X, Study Group of I, Guan XD (2018) Terlipressin versus norepinephrine as infusion in patients with septic shock: a multicentre, randomised, double-blinded trial. Intensive Care Med 44:1816-1825

12. Martensson J, Gordon AC (2018) Terlipressin or norepinephrine, or both in septic shock? Intensive Care Med 44:1964-1966

13. Moller MH, Claudius C, Junttila E, Haney M, Oscarsson-Tibblin A, Haavind A, Perner A (2016) Scandinavian SSAI clinical practice guideline on choice of first-line vasopressor for patients with acute circulatory failure. Acta Anaesthesiol Scand 60:1347-1366

14. Nagendran M, Russell JA, Walley KR, Brett SJ, Perkins GD, Hajjar L, Mason AJ, Ashby D, Gordon AC (2019) Vasopressin in septic shock: an individual patient data meta-analysis of randomised controlled trials. Intensive Care Med 45:844-855

15. Lewis RJ, Angus DC, Laterre PF, Kjolbye AL, van der Meulen E, Blemings $A$, Graves T, Russell JA, Carlsen JE, Jacobsen K, Yealy DM, Opal SM, Windelov NA, Francois B, Perner A, Pickkers P, Berry SM (2018) Rationale and design of an adaptive phase $2 b / 3$ clinical trial of selepressin for adults in septic shock. Selepressin evaluation programme for sepsis-induced shock-adaptive clinical trial. Ann Am Thorac Soc 15:250-257

16. Khanna A, English SW, Wang XS, Ham K, Tumlin J, Szerlip H, Busse LW, Altaweel L, Albertson TE, Mackey C, McCurdy MT, Boldt DW, Chock S, Young PJ, Krell K, Wunderink RG, Ostermann M, Murugan R, Gong MN, Panwar R, Hastbacka J, Favory R, Venkatesh B, Thompson BT, Bellomo R, Jensen J, Kroll S, Chawla LS, Tidmarsh GF, Deane AM, Investigators A (2017) Angiotensin II for the treatment of vasodilatory shock. N Engl J Med 377:419-430

17. Teboul JL, Duranteau J, Russell JA (2018) Intensive care medicine in 2050: vasopressors in sepsis. Intensive Care Med 44:1130-1132

18. Whitson MR, Mo E, Nabi T, Healy L, Koenig S, Narasimhan M, Mayo PH (2016) Feasibility, utility, and safety of midodrine during recovery phase from septic shock. Chest 149:1380-1383 